\title{
Displaced and misplaced genitives
}

\author{
Josef Bayer
}

\section{Data}

German has a peculiar extraposition construction which to my knowledge has not received much attention so far. The reason could be that this construction appears mainly in spoken language, but I will show below also some rare examples from literary sources. The construction is peculiar because the extraposed element is a post-nominal genitive DP, a kind of DP that is normally not considered to be mobile at all. The following examples were observed in radio- or TV-debates or in academic discourse.

(1) Zwei Tage haben wir Renntage der Woche. two days have we racing-days the week $_{\text {gen }}$ 'Two days of the week we have racing days.'

(Westdeutscher Rundfunk, 1991)

(2) Künstler, die ich schätze, aller Zeiten, haben sich artists who I like all times ${ }_{\text {gen }}$ have REF mit dem Tod beschäftigt. with the death dealt 'Artists of all times who I like have dealt with the topic of death.'

(Wolf Vostell in an interview, Westdeutscher Rundfunk, 1992)

(3) daß man die fundamentalen Daten angeschaut hat that one the fundamental data observed has der amerikanischen Wirtschaft.

the American economy ${ }_{\text {gen }}$ 'that one has taken a look at the fundamental data of the American economy.'

(4) Der Dativ kann nicht als Rezipient fungieren der Handlung. the dative can not as recipient function the action ${ }_{\text {gen }}$ 'The dative cannot function as the recipient of the action.'

(Susan Olsen, Talk in Jena, 1996) 
(5) ... wo eine große Vernetzung schon neuropsychologischer where a huge linkage already neuropsychological Forschung stattgefunden hat. research $_{\text {gen }}$ place-found has 'where a huge linkage of neuropsychological research has already taken place.' (academic discussion, 2003)

(6) Das scheint mir das Problem zu sein der Auswertung [...]. this seems me the problem to be the evaluation ${ }_{\text {gen }}$ 'To me, this seems to be the problem of the evaluation.'

(Roland Koch, ARD, 2005)

Searching for examples in written texts is cumbersome, but there are nevertheless the following which I found in E. Henscheid (1988/1997), Maria Schnee. Eine Idylle. Frankfurt Zweitauseneins.

[...], aus dem Hausflur hörte man das Bellen jetzt des Hundes from the corridor heard one the barking now the $\operatorname{dog}_{\text {gen }}$ 'from the corridor one could now hear the barking of the dog.'

(Maria Schnee, p.57)

(8) Ein Killerkommando sei auf ihn heute angesetzt

a killer-squad be on him today put

des Staatsschutzes, sagte er mild, man bezichtige ihn the state securitygen said he mildly one accuse him des Hochverrats. the high treason 'A killer-squad of the state security is supposed to be put on him today, he said mildly, one accuses him of high treason.'

(Maria Schnee, p. 66)

Behaghel (1932: 194ff) states that the post-nominal genitive usually stays closest to the noun, but he also notices that this constraint may be violated, the genitive appearing at a distance. He mentions only examples as in (9) in which it appears that the genitive remains in the DP.

(9) diese günstige Art zu denken des Herrn Zürchers this comfortable way to think the Mr. Zürcher ${ }_{\text {gen }}$ 'Mr. Zürcher's comfortable way of thinking' 
But Ebert (2003: 196) reports findings from Martin Luther's writings which leave no doubt that the genitive has been extraposed to the end of the sentence because it follows the verb.

(10) Ich will euch auch etliche exempel erzelen

I want you also some examples tell

des Christlichen rechts

the Christian right

'I would like to give you some examples of Christian right.'

(11) ist er [...] der ergest feynd gewesen Gottes

is he the worst enemy been $\operatorname{god}_{\text {gen }}$

und seynes worttes.

and his word $\mathrm{gen}_{\text {en }}$

'he was the worst enemy of god and his word'

Thus even if this construction does not seem to belong to the core of modern written Standard German, there can be no doubt that it is alive as a legitimate possibility.

\section{Extraposition = Raising plus Remnant Movement?}

It appears to be rather unclear why a post-nominal genitive would move to the end of the clause. There is no indication of a core grammatical reason. In generative grammar, extraposition has traditionally been analyzed as a process of right adjunction. If one does not want to subscribe to admitting a linearly reversed 'gap-filler' dependency, the prediction is that the extraposed phrase escapes binding relations that normally work from left to right. Intuitions about binding into extraposed genitives suggest, however, that they are as 'low' in the phrase marker as anything else in the right periphery that has been considered in the literature.

(12) Jeder Angestellte mußte der Frau gratulieren.

each employee must the wife congratulate

seines Vorgesetzten.

his boss $_{\text {gen }}$

'Each employee hat to congratulate the wife of his boss.' 
(13) Man hat keinem Arbeiter den Dienstwagen gezeigt one has no worker the official-car shown seines Chefs.

his boss gen

'One hasn’t shown any worker the official car of his boss.'

In both of these cases the possessive pronoun of the extraposed genitive is bound by the preceding quantified DP as if it had stayed in place. So extraposition in the sense of right adjunction would have to be trace related so that the remaining copy can be used for interpretation.

If c-command has to go hand in hand with a consistent linear order, as Kayne's (1994) LINEAR CORRESPONDENCE AXIOM (LCA) requires, right adjunction is untenable, for a principled reason. Movement cannot induce a c-command relation that simultaneously works from left to right and from right to left. A popular solution to the extraposition problem has therefore been to decompose extraposition into two processes of leftward movement. In a first step, the phrase to be extraposed is moved to the left. In a second step the remaining phrase, the 'remnant', is moved across the formerly extracted phrase. So the 'extraposed' element is essentially stranded. Example (3) would accordingly be derived as in (14).

(14) a. man [die fundamentalen Daten [der amerikanischen Wirtschaft]] angeschaut hat $\quad$ SCRAMBLING $\Rightarrow$

b. [der amerikanischen Wirtschaft $]_{1}$ man [die fundamentalen Daten $\mathrm{t}_{1}$ ] angeschaut hat REMNANT MOVEMENT $\Rightarrow$

c. [man [die fundamentalen Daten $\mathrm{t}_{1}$ ] angeschaut hat $]_{2}$ [der amerikanischen Wirtschaft $]_{1} \mathrm{t}_{2} \quad$ MERGER OF $\mathrm{C} \Rightarrow$

d. [daß [man [die fundamentalen Daten $\mathrm{t}_{1}$ ] angeschaut hat $]_{2}$ [der amerikanischen Wirtschaft $]_{1} \mathrm{t}_{2}$ ]

In the resulting representation in (14d) the conflict with the LCA has been overcome. There is uniformity of leftward movement, albeit involving traces which are only bound under reconstruction, but this is an aspect that should not concern us here. The question is whether the movements shown in the transition from (14a) to (14b) to (14c) are motivated in some sense. While scrambling is an attested option in German, the movement of the remnant in (14c) has hardly any independent motivation. But apart from the latter problem we should ask whether the scrambling of a genitive DP is an option of German syntax. And here the answer is clearly negative. As a matter of fact, no example at all seems to be acceptable in which an 
adnominal genitive has undergone leftward movement, be it by scrambling or by the less marked option of movement to SpecCP in V2-constructions. The following versions of (1) through (6) in which the genitive DP has been moved to SpecCP are sharply ungrammatical.

(1') *Der Woche ${ }_{1}$ haben wir zwei Tage $t_{1}$ Renntage.

(2') *Aller Zeiten ${ }_{1}$ schätze ich Künstler $\mathrm{t}_{1}$, die ...

(3') *Der amerikanischen Wirtschaft $t_{1}$ hat man die fundamentalen Daten $\mathrm{t}_{1}$ angeschaut.

(4') *Der Handlung ${ }_{1}$ kann der Dativ nicht als Rezipient $\mathrm{t}_{1}$ fungieren.

(5') *Neuropsychologischer Forschung ${ }_{1}$ hat schon eine große Vernetzung $t_{1}$ stattgefunden.

(6') *Der Auswertung 1 scheint mir das das Problem $t_{1}$ zu sein.

This is clearly at variance with other forms of extraposition such as PPextraposition. PPs can usually move to the left, and therefore it is conceivable that they undergo a grammatically licit process before remnant movement applies. For adnominal genitives this option must, however, be discarded. I have no clear idea as to why this should be the case. One reason could be that DP is a bounding node which can only be crossed by a first step of movement to SpecDP. Genitive DPs in SpecDP are generally impossible, while PPs in SpecDP are frequent, at least in spoken language. ${ }^{1}$

(15) a. *[der amerikanischen Wirtschaft $t_{1}$ [die fundamentalen Daten] $\mathrm{t}_{1}$ ] the American economygen the fundamental data

b. ${ }^{(?)}$ [von der amerikanischen Wirtschaft ${ }_{1}$ [die fundamentalen Daten] $\mathrm{t}_{1}$ ] of the American economy the fundamental data

While (15a) is ungrammatical for any speaker of German, (15b) is possible for many speakers, and the difference between (15a) and (15b) can certainly also be appreciated by those who are less than happy with (15b). Modern German has bona fide genitives almost exclusively in post-nominal position. Pre-nominal genitives as in des Kaisers neue Kleider (the

${ }^{1}$ Notice, however, that in Early New High German genitives could precede the indefinite article. The following example is again from Luther.

(i) des zorns eyn gros teyl

the wrath-GEN a big part

'a big part of the wrath' 
emperor $_{\text {gen }}$ new clothes, 'the emperor's new clothes') seem to be unproductive residues in the language. Since the pre-nominal genitive usually determines the DP, and may even be compatible with the features for definite reference when the genitive is an indefinite DP as in eines

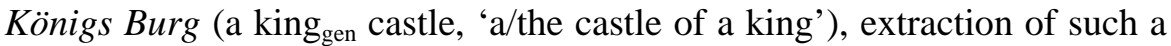
genitive DP would leave the head-DP undetermined. Outside the familiar cases - bare plurals, mass nouns etc. - non-determination is however not an option in an 'article language' like German. We can thus conclude that the extraposed genitive is neither a hidden pre-nominal nor a hidden postnominal genitive which uses SpecDP as an escape position for the purpose of scrambling or A-bar topicalization. ${ }^{2}$

The derivation seen in (14a) through (14c) is not only lacking independent motivation, it involves two movements that are as such forbidden in the language. The two steps appear to yield an acceptable and empirically attested result only in combination, and I hasten to say, by an extrinsic ordering of these two steps. Given this state of affairs, the only purpose of remnant movement can be to fix up an otherwise ungrammatical output. This kind of movement has become known within Optimality Theory as 'repair-driven movement' (cf. Heck and Müller, 2000). This is not the right place to review arguments in favor of repair movement as an additional and obviously secondary type of movement. Strategically it seems to me more desirable to explore other possibilities before adopting such powerful options.

\section{In Search for an Alternative}

The results we have reached at this point are the following:

- The extraposed genitive behaves semantically as if it had remained in situ

- There is no tangible motivation for any of the two steps that would be necessary to derive genitive extraposition in agreement with the LCA.

In this situation it is fair to ask whether extraposition (in particular of a genitive DP) should be considered to be a core syntactic operation at all. My suggestion is that it should not. Following the minimalist strategy of deriving movement from output conditions, phonological phrasing seems to

\footnotetext{
${ }^{2}$ Given that SpecDP is an A-bar and potential operator position, scrambling would also induce a conflict with the chain requirement of proper binding.
} 
be a reasonable alternative to operations of core grammar, i.e. operations which include feature management with respect to semantics. Truckenbrodt (1995) has in fact suggested that extraposable elements may be attached to the right of their minimal containing XP for prosodic reasons. The categories to be moved respect syntactic categories but are autonomously determined by prosodic phonology. According to the prosodic hierarchy, they would be intonation phrases (IP), phonological phrases ( $\phi$ ), phonological words $(\omega)$ etc. Truckenbrodt suggests that a phrase that is displaced to the right attaches to a phrase of the same category such that a proper phrasal linearization results. German offers good evidence for this. Consider the following example from Bayer, Schmid and Bader (2005).

(16) a. $\quad(\text { Die Leute })_{\phi}$ (waren drauf stólz $)_{\phi} \quad$ EXTRAPOSITION $\Rightarrow$ the people were there-of proud

b. (Die Leute $)_{\phi}$ (waren drauf (stólz) $\left.)_{\omega}(\text { drauf })_{\omega}\right)_{\phi}$

In (16b) the phonological word drauf has been attached to the right of the phonological word stolz which carries the main stress. A short word like this pronominal PP would be awkward had it been attached in unreduced form as a phonological phrase.

$$
\text { ??(Die Leute } \left.\left.)_{\phi} \text { (waren darauf (stólz) }\right)_{\omega}\right)_{\phi}(\text { dárauf })_{\phi}
$$

The spoken language examples which have been listed in section 1, on the other hand, are well compatible with the requirement that the genitive DP is a phonological phrase which attached to the right of another phonological phrase, or an intonation phrase (IP) that is attached to the right of another intonation phrase. The phrases seem to be balanced in length.

(1") (Zwei Tage der Woche $)_{\phi}$ (haben wir Renntage $)_{\phi}$ (der Woche $)_{\phi}$

$\left(2^{\prime \prime}\right) \quad$ (Künstler aller Zeiten $)_{\phi}$ (die ich schätze) $)_{\phi}$ (aller Zeiten) $)_{\phi}, \ldots$

$\left(3^{\prime \prime}\right) \quad$ (daß man die fundamentalen Daten der amerikanischen Wirtschaft angeschaut hat) $)_{I P}$ (der amerikanischen Wirtschaft) ${ }_{\text {IP }}$

(4") Der Dativ kann nicht (als Rezipient der Handlung fungieren) $)_{\phi}$ (der Handlung $)_{\phi}$

$\left(5^{\prime \prime}\right) \quad$ (wo eine große Vernetzung neuropsychologischer Forschung schon $)_{\phi}$ (neuropsychologischer Forschung $)_{\phi}$ (stattgefunden hat) $)_{\phi}$ 
$\left(6^{\prime \prime}\right) \quad$ (Das scheint mir $)_{\phi}$ (das Problem zu sein der Auswertung $)_{\phi}$ (der Auswertung $)_{\phi}$

Similar phrasings appear to be plausible for the written language examples. I see them as readjustments of the phrase structure that apply before SpellOut in the service of prosodic optimization. Importantly, they do not alter the syntactic representations that are indicated by cross-out. It is thus expected that the extraposed genitives behave as if they had been reconstructed into their base position. ${ }^{3}$

\section{Conclusion}

From a purely syntactic point of view, the extraposition of genitive DPs which is found in (mainly spoken) German is a strange phenomenon. We have shown that there are two analyses both of which are struck with empirical problems, and both of which lack conceptual attractivity. Tracerelated right-adjunction is untenable for various reasons that have been around in linguistics since Ross (1967), and especially since Kayne (1994). The reanalysis of extraposition in terms of multiple leftward movement may be technically feasible, but conceptually it makes things just worse. While tradition extraposition involves one unmotivated step, the syntactic derivation with multiple leftward movement simply adds another unmotivated step, namely remnant movement. The leftward movement analysis could claim that XP-raising (scrambling or $\mathrm{A}^{\prime}$-movement) is motivated as an option of the grammar of German, and that remnant movement belongs to UG anyway. However, in German XP-raising can never affect an adnominal genitive DP. So this motivation is gone for good. As a consequence, movement of the remnant reduces to nothing else but 'repair movement'. I take this as a strong motivation to look for an alternative account. I have very briefly sketched an account of genitive extraposition in terms of prosodic readjustment. If a phonological account of this sort is on the right track, core syntax does not need to be burdened with ill-motivated operations like genitive displacement. Better job-sharing between syntax and phonology would result in a picture of grammar that seems more compatible with the philosophy of minimalism and with a modular approach to language.

\footnotetext{
${ }^{3}$ Since extraposition is not considered a syntactic process of movement as, for instance, in Büring and Hartmann (1997), the crossed-out copies in (1') through (6') should not be misunderstood as traces.
} 
Even if he does not agree with the details of my description of the data, I am sure that Henk van Riemsdijk, who has in his work frequently emphasized that syntacticians should learn from phonologists, would agree with this conclusion.

\section{References}

Bayer, Josef, Tanja Schmid and Markus Bader. 2005. Clause Union and Clausal Position. In The function of function words and functional categories, ed. by Marcel den Dikken and Christina Tortora, 79-113. Amsterdam: John Benjamins.

Behaghel, Otto. 1932. Deutsche Syntax. Band IV. Wortstellung und Periodenbau. Heidelberg: Carl Winter.

Büring, Daniel and Katharina Hartmann. 1997. Doing the right thing. The Linguistic Review 14. 1-42.

Ebert, Robert P. 2003. Die Stellung des attributiven Genitivs in Luthers Schriften. Sprachwissenschaft 28. 195-229.

Heck, Fabian and Gereon Müller. 2000. Repair-driven movement and the local optimization of derivations. unpublished ms. University of Stuttgart and Institut für deutsche Sprache, Mannheim.

Kayne, Richard S. 1994. The antisymmetry of syntax. Cambridge, MA: MIT Press. Ross, John R.1967. Constraints on variables in syntax. Ph.D. dissertation, MIT Cambridge, Massachusetts.

Truckenbrodt, Hubert. 1995. Extraposition from NP and prosodic structure. NELS 25: 503-517. 